\title{
17 \\ Political capital and wealth accumulation
}

\section{Meng Xin}

The economic-well being of individuals during old age, unemployment and sickness is closely related to their private wealth, especially in an economy where government has little ability or desire to redistribute income or provide adequate social insurance. China is in the process of moving from state provision of all social welfare towards a new system that will rely heavily on individual's responsibilities. In this new economic environment, the accumulation and distribution of personal wealth will play an important role. This study investigates changes in private wealth accumulation in urban China. In particular, we are interested in examining the effect of political status in the process of wealth accumulation.

\section{BACKGROUND}

In the pre-reform era in urban China, three important factors discouraged individual households from accumulating personal wealth: 1. a low income level, 2. a wellprovided social welfare system, and 3 . the lack of financial, housing and other important durable goods markets. These three factors have gradually changed with progress in economic reform. Over the last twenty or so years incomes of urban population increased from 343 yuan in 1978 to 5854 yuan in 1999, an annual increase of 14.5 per cent (NSB, 2000). In addition, business opportunities have flourished. In 1999, the proportion of urban workers working in the private sector increased to 51 per cent while this ratio was 0.2 per cent in 1978 (NSB 2000). More 
importantly, since the late 1980s, economic reform gradually swept away almost all aspects of the old social security system at the same time as state-owned enterprises started to lay off large numbers of workers. All these factors have significantly increased households savings. This, in turn, has generated a significant increase in wealth accumulation in urban China.

In addition to the speed of wealth accumulation, the process of wealth accumulation and distribution in urban China has special features. One important feature is the role of political power in the acquisition of wealth. Even though political power has always benefited high-level government and party officials, economic reform has commercialised this power through the distribution of labour and non-labour income (Morduch and Sicular 2000) and the distribution of housing. For example, in the old system, the size and quality of housing was determined by individuals' political power and occupational status. Housing reform introduced in the early 1990 s allowed those who were renting government housing to buy their dwellings at a heavily subsidised price. The subsidy was positively related to the seniority and political positions of household members. Thus, the acquisition of housing, which accounted for more than half of the average household wealth in 1999, is affected by political factors on two accounts-the initial allocation of better housing and larger purchase price discounts. Another example of the influence of political power is the importance of networking in establishing a private business. Those with political power or those well connected to political power find it easier to establish and succeed in private enterprises. Furthermore, widespread corruption during the process of marketisation gives people with political power an extra means to gain non-labour income.

Another unique feature in personal wealth accumulation and distribution in urban China is the way in which inheritance takes place. The lack of wealth among the older generation means that inheritance is not important. Children of important government or party officials, however, can easily inherit business networks and political connections. In addition, in the pre-reform era, children of individuals with political power were normally able to acquire better housing which subsequently could be purchased at highly subsidised prices.

\section{METHODOLOGY AND DATA}

To study wealth accumulation, the specifications used in Carroll and Samwick (1997) and Shamsuddin and DeVoretz (1998) are used as a base model:

$\log W_{i}=\alpha_{0}+\alpha_{1} V_{i}+\alpha_{2} \log P_{i}+\alpha_{3} P$ arty $+X \beta^{W}+u_{i}$ 
where $W_{i}$ is wealth, $V_{i}$ is variance of household income, and $P_{i}$ is an estimate of permanent income, which is defined as weighted average of past incomes. Party is a dummy variable indicating whether or not an individual is a party member or not, and $X_{i}$ is a vector of other exogenous variables.

In this specification $V_{i}$ indicates the effect of precautionary saving, Party ${ }_{i}$ captures the effect of political power. The vector of endogenous variables $X_{i}$ controls for life cycle and bequest effects of wealth accumulation. The variables included in $X_{i}$ are age, number of children, household size, whether the household has unemployed member(s), and household location of residence. The variable 'permanent income', $P_{i}$, normally captures differences in saving behaviour and in wealth acquired from non-saving sources among households with different levels of expected lifetime income. In the West, non-saving wealth accumulation is mainly through inheritance or lotteries. In urban China during the period we are studying, inheritance and lotteries are not important. Rather, direct transfers from state to individuals, such as highly subsidised housing or other forms of non-saving wealth, such as gifts, or even bribes, may form the main part of the non-saving wealth.

One important issue in estimating Equation 17.1 is the possible endogeneity of the variables 'permanent income' and 'the variance of household income'. To endogenise these two variables, a vector of instruments is used. These instruments should be important determinants of permanent income and variance of income but have no predictive power on wealth over and above their effect on these two variables. We include years of schooling for household head and spouse, industry and ownership affiliations of household heads in the vector of the instruments.

The data used in this study are from two Urban Household Income Distribution Surveys (UHIDS) conducted by the Institute of Economics, Chinese Academy of Social Sciences for the years 1995 and 1999. The surveys include 6930, and 4493 households for the two years, respectively. The 1995 survey covers 11 provinces, whereas the 1999 survey covers 6 of the 11 provinces included in the previous surveys. To ensure the consistency of the comparison, only observations from the 6 provinces which are surveyed in both years are included. Excluding missing values, the number of households included in this study vary from 3626 to 3748 for 1995 survey and from 4296 to 4363 for the 1999 survey depending on the group of variables used in each estimation.

Table 17.1 reports summary statistics and measures of inequality of household income, permanent income and different types of wealth for the two survey years. 
Over the 4 year period, real permanent household income increased by 16 per cent per annum and real net wealth increased by 24 per cent per annum. The fact that real wealth growth is much faster than real income growth suggests that either the saving propensity has increased significantly or a large proportion of the wealth accumulation is coming from non-saving sources, or both. Among the total wealth, housing wealth has grown the fastest, at a rate of 42 per cent per annum. This is mainly due to the faster pace of housing reform during this period. Table 17.2 shows that in 1988, hardly any household owned its own house. By 1995, 26 per cent of the households had bought their own house, while this ratio increased to 58 per cent

\section{Table 17.1 Summary statistics and inequality measures of real income and wealth, 1995 and 1999}

\begin{tabular}{lcccc}
\hline & $\begin{array}{c}\text { Permanent } \\
\text { income }\end{array}$ & $\begin{array}{c}\text { Net total } \\
\text { wealth }\end{array}$ & $\begin{array}{c}\text { Financial } \\
\text { wealth }\end{array}$ & $\begin{array}{c}\text { Net housing } \\
\text { wealth }\end{array}$ \\
$1995(1995=100)$ & 6261.24 & 32047.90 & 11673.86 & 10920.41 \\
Mean & 2987.42 & 40436.34 & 23097.01 & 26322.86 \\
Std. Dev. & 0.48 & 1.26 & 1.98 & 2.41 \\
Coefficient of variation & 0.52 & 1.07 & 1.17 & 1.03 \\
Standard deviation of logs & 0.25 & 0.50 & 0.58 & 0.84 \\
Gini coefficient & & & & \\
1999 (1995=100) & 11426.31 & 75515.01 & 22574.62 & 44171.64 \\
Mean & 6626.07 & 85256.71 & 34380.20 & 65768.57 \\
Std. Dev. & 0.58 & 1.13 & 1.52 & 1.49 \\
Coefficient of variation & 0.55 & 1.28 & 1.28 & 0.91 \\
Standard deviation of logs & 0.29 & 0.52 & 0.63 & 0.65 \\
Gini coefficient & & & & \\
Annual growth rate 1995-99 & 16.2 & 23.90 & 17.92 & 41.82 \\
(per cent) & & & & \\
\hline
\end{tabular}

Table 17.2 Effect of housing reform on housing ownership, 1988-99

\begin{tabular}{lcccccc}
\hline & \multicolumn{2}{c}{1988} & \multicolumn{2}{c}{1995} & \multicolumn{2}{c}{1999} \\
Public housing & 3577 & 85.11 & 2436 & 63.31 & 1621 & 36.17 \\
Old self housing & 611 & 14.54 & 419 & 10.89 & 258 & 5.76 \\
Bought after reform & 15 & 0.36 & 993 & 25.81 & 2602 & 58.07 \\
& 4203 & & 3848 & & 4481 & \\
\hline
\end{tabular}

Sources: Household Income Distribution Surveys, 1988, 1995, and 1999, Institute of Economics, the Chinese Academy of Social Sciences. 
in 1999. The majority of houses purchased during the housing reform period were bought at highly subsidised prices, and may account for a large part of the nonsaving wealth accumulation. Nevertheless, the rate of increase in financial wealth (17 per cent per annum) is also faster than the increase in real income, indicating possible non-savings accumulation of financial wealth as well.

Another interesting issue is the difference in the speed of asset accumulation between the rich and the poor. To investigate this issue, we rank household permanent income into percentiles and calculate for each percentile average net household total wealth for 1995 and 1999. Figure 17.1 presents the results as well as the growth rate for each percentile. Over this period net household total wealth increased for households in all percentile of income, but the rate of increase is much higher for the above average rich households than for the poor.

\section{DETERMINANTS OF WEALTH}

To further investigate the determinants of wealth and wealth distribution, Equation 17.1 is estimated using the 1995 and 1999 UHIDS data. The results using IV estimation for the net total wealth, financial wealth, and net housing wealth are reported in Tables 17.3, 17.4, and 17.5, respectively. In each of these tables, the first column presents the results using the 1995 data while the second and the third columns provide results using the 1999 data. Note that in the third column a variable indicating whether the father of the household head is a party member or not is included. Even though important, this variable is not available from the 1995 data. To make it comparable between the two years, we estimated Equation 17.1 with and without this variable for 1999 data.

The first important finding is the difference in the effect of permanent income on wealth between the two years. With regard to net total wealth, the income elasticity of wealth is less than one in 1995 but increased to 1.6 in 1999. The fast change in the elasticity during this period may imply one of three things. First, relative to the poor the rich have been saving much more during this period providing that all wealth is accumulated from savings. However, given the significant increase in wealth during such a short period it is unlikely that all wealth is accumulated through personal savings. Second, the rich may have been given much more wealth than the poor. This wealth may be given in the form of direct wealth, such as housing, or in the form of income, such as gifts or even monetary bribes. If it is in the form of income, our finding suggests that the rich in the sample are under-reporting their 
Figure 17.1 Lorenz curves of wealth

Panel A: Net total assets, 1995 and 1999

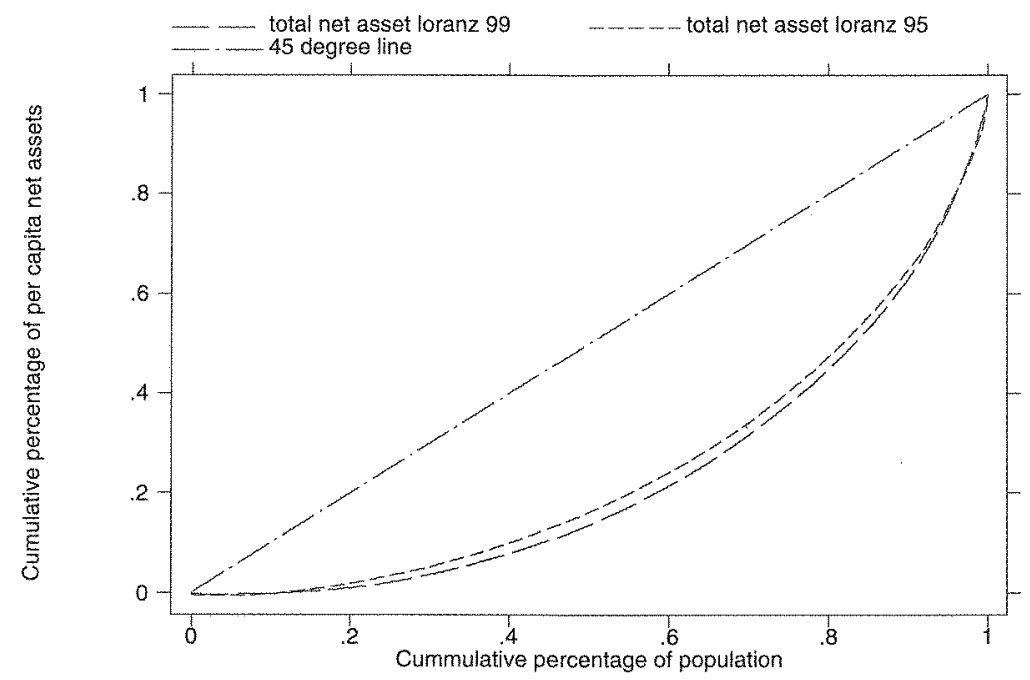

Panel B: Financial assets, 1995 and 1999

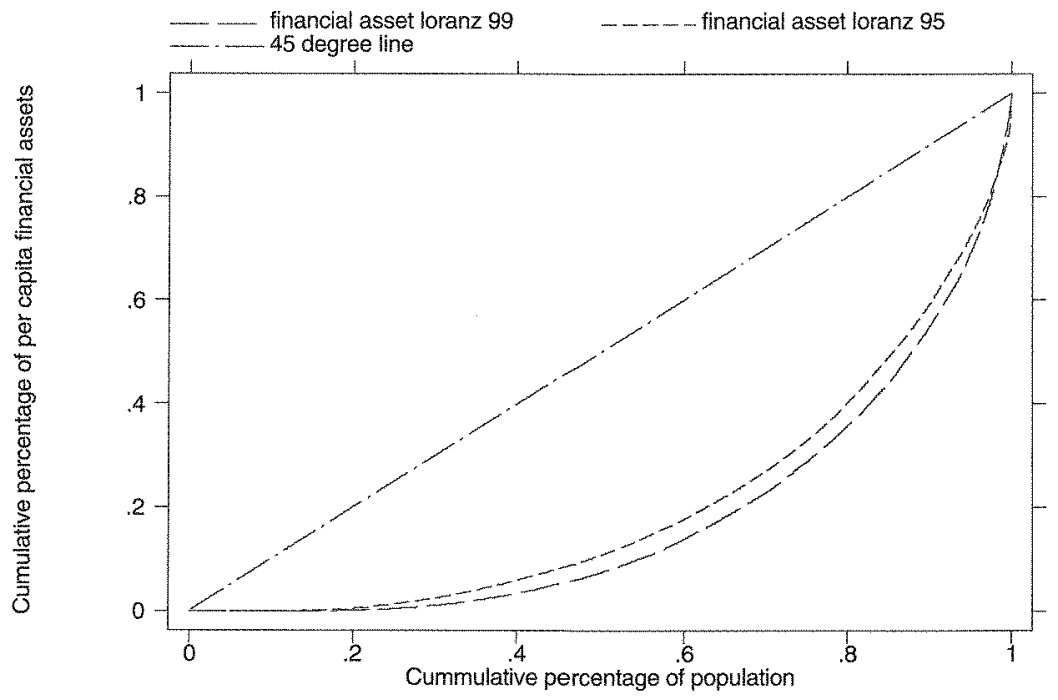


Panel C: Net housing assets, 1995 and 1999

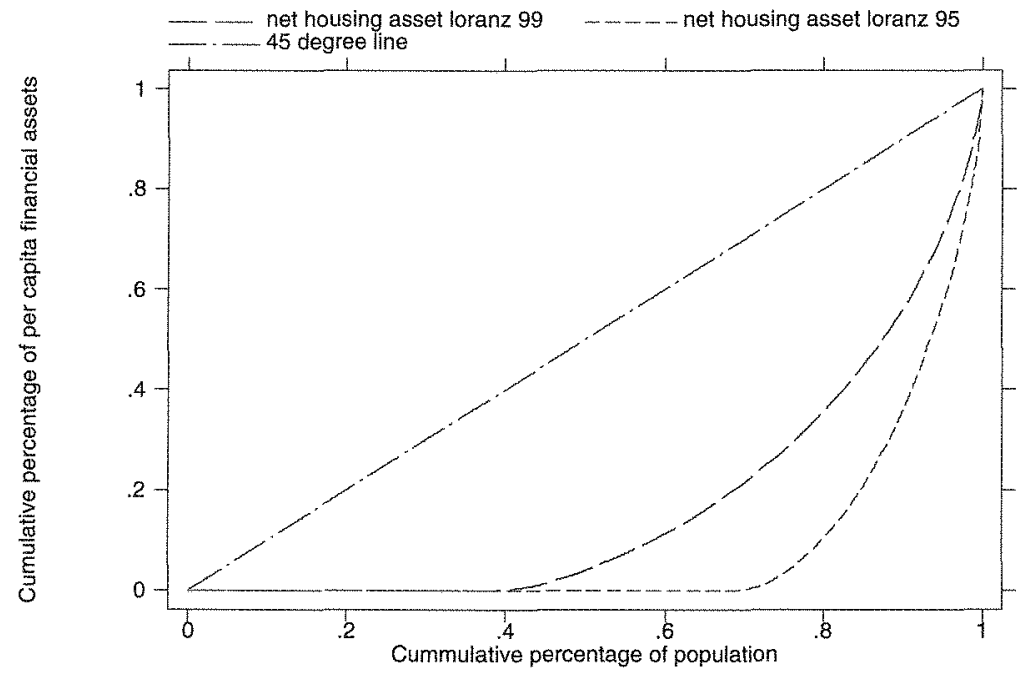

income. Either way, this is an important indication that the rich have been able to accumulate wealth via non-economic means. To provide some evidence, we calculated for each income percentile its annual growth rate in income and saving rate. The net total asset level in 1999 is then projected assuming that net assets are accumulated only through saving. Figure 17.3 shows the result. It clearly indicates that projected wealth is lower than actual wealth for households in all income percentiles. However, the amount of non-saving wealth is much higher for the households with above-average income level, than for the poor. For example, households below the 50 th percentile income level on average acquire 39 per cent of their accumulated wealth from non-saving component, while this ratio for those above the $50^{\text {th }}$ percentile is 50 per cent. The third possibility is that the existing wealth has appreciated at a very high rate. This, however, is unlikely to explain a large part of the difference. The type of wealth which is most likely to have appreciated is housing. According to the China Statistical Yearbook (2002), the commercial housing prices (per square metre) increased by 29 per cent from 1995 to 1999. Taking into account that net housing wealth accounted for 41 per cent of net total wealth in 1999 in our sample, ${ }^{1}$ we projected the effect of housing price appreciation 
Table 17.3 Determinants of net total wealth, 1995 and 1999 (IV estimates)

\begin{tabular}{|c|c|c|c|c|c|c|}
\hline \multirow[b]{3}{*}{ Lntass } & \multirow{2}{*}{\multicolumn{2}{|c|}{1995}} & \multicolumn{4}{|c|}{1999} \\
\hline & & & \multicolumn{2}{|c|}{ without father } & \multicolumn{2}{|c|}{ with father } \\
\hline & Coef. & Std. Err. & Coef. & Std. Err. & Coef. & Std. Err. \\
\hline Constant & 2.50 & 2.99 & $-5.66^{*}$ & 2.56 & $-5.75^{* *}$ & 2.56 \\
\hline Log permanent income & $0.79^{*}$ & 0.41 & $1.62^{\mathrm{mm}}$ & 0.31 & $1.62^{* * n}$ & 0.31 \\
\hline \multicolumn{7}{|l|}{ Variance of household } \\
\hline income/10 $10^{7}$ & -0.20 & 0.18 & $0.05^{*}$ & 0.03 & $0.05^{*}$ & 0.03 \\
\hline $\mathrm{HH}$ being party member & $0.27^{* *}$ & 0.08 & $0.20^{*}$ & 0.09 & $0.19^{*}$ & 0.08 \\
\hline Father of $\mathrm{HH}$ being pty member & & & & & 0.08 & 0.08 \\
\hline No. of unemployed & -0.09 & 0.10 & $-0.23^{\prime *}$ & 0.10 & $-0.23^{*+*}$ & 0.10 \\
\hline $\mathrm{HH}$ age & 0.03 & 0.04 & 0.03 & 0.03 & 0.03 & 0.03 \\
\hline $\mathrm{HH}$ age squared/100 & -0.04 & 0.04 & -0.03 & 0.03 & -0.03 & 0.03 \\
\hline Gender of the $\mathrm{HH}$ & 0.10 & 0.09 & 0.13 & 0.08 & 0.13 & 0.08 \\
\hline Family size & 0.15 & 0.10 & $-0.21^{*}$ & 0.11 & $-0.21^{*}$ & 0.11 \\
\hline No. of children & -0.18 & 0.12 & 0.07 & 0.13 & 0.07 & 0.13 \\
\hline Proportion of elderly members & .0 .45 & 0.71 & 0.02 & 0.64 & 0.00 & 0.64 \\
\hline Proportion of elderly members ${ }^{2}$ & 0.56 & 0.74 & 0.44 & 0.66 & 0.47 & 0.66 \\
\hline Liaoning & -0.37 & 0.23 & $1.01^{\cdots *}$ & 0.17 & $1.00^{\circ+1}$ & 0.17 \\
\hline Jiangsui & -0.26 & 0.24 & $1.05^{\text {k*s }}$ & 0.15 & $1.05^{4+1+}$ & 0.15 \\
\hline Henan & -0.19 & 0.22 & $0.87^{\text {tns }}$ & 0.18 & $0.86^{*+}$ & 0.18 \\
\hline Sichuan & $-1.40^{n+*}$ & 0.21 & $0.95^{\circ *}$ & 0.17 & $0.95^{n+x}$ & 0.17 \\
\hline Gansu & $-1.34^{x+x}$ & * 0.28 & 0.20 & 0.20 & 0.19 & 0.20 \\
\hline No. of observations & 3748 & & 4296 & & 4296 & \\
\hline $\mathrm{R}^{2}$ & 0.070 & & 0.098 & & 0.099 & \\
\hline
\end{tabular}

on net total wealth. It is also plotted in Figure 17.3 (the thicker line). The predicted net total wealth level, taking into account the appreciation in 1999 , is still much lower than the actual level for the middle and high income households.

The second important finding is the change in the effect of the variance in household income on wealth accumulation. In 1995, this variable played no role. A positive effect, however, is observed in 1999, indicating that households which have experienced large income variation over the 5 years prior to the survey year saved more than households which have had more stable incomes. This finding accords well with the reality. The radical state sector reform and social welfare reform during the second half of the 1990s has significantly increased household saving propensity due to the expected increase in unemployment and individual contribution in the areas of medical services, pension, children's education, and housing. In order to 
Table 17.4 Determinants of financial wealth, 1995 and 1999 (IV estimates)

\begin{tabular}{|c|c|c|c|c|c|c|}
\hline \multirow[b]{3}{*}{ Lfass } & \multirow{2}{*}{\multicolumn{2}{|c|}{1995}} & \multicolumn{4}{|c|}{1999} \\
\hline & & & \multicolumn{2}{|c|}{ without father } & \multicolumn{2}{|c|}{ with father } \\
\hline & Coef. & Std. Err. & Coef. & Std. Err. & Coef. & Std. Err. \\
\hline Constant & -12.47 & 3.70 & $-22.87^{*+*}$ & 3.84 & $-23.07^{+50}$ & 3.84 \\
\hline Log permanent income & $2.49^{* * *}$ & 0.51 & $3.32^{\operatorname{snn}}$ & 0.46 & $3.33^{x+*}$ & 0.47 \\
\hline Variance of household income $/ 10^{7}$ & -0.32 & 0.21 & $0.08^{\star}$ & 0.04 & $0.08^{*}$ & 0.04 \\
\hline $\mathrm{HH}$ being party member & $0.42^{* * *}$ & 0.11 & $0.29^{* *}$ & 0.13 & $0.27^{+* *}$ & 0.13 \\
\hline Father of $\mathrm{HH}$ being pty member & & & & & 0.17 & 0.12 \\
\hline No. of unemployed & -0.21 & 0.14 & -0.03 & 0.13 & -0.03 & 0.13 \\
\hline $\mathrm{HH}$ age & 0.04 & 0.04 & 0.06 & 0.04 & 0.06 & 0.04 \\
\hline $\mathrm{HH}$ age squared/100 & -0.05 & 0.05 & $-0.10^{*}$ & 0.04 & $-0.10^{*}$ & 0.04 \\
\hline Gender of the HH & -0.03 & 0.11 & $0.31^{+2 n+}$ & 0.12 & $0.31^{+\infty}$ & 0.12 \\
\hline Family size & -0.20 & 0.14 & $-0.93^{* \times x}$ & 0.18 & $-0.92^{* * *}$ & 0.18 \\
\hline No. of children & -0.04 & 0.16 & $0.62^{* * n}$ & 0.20 & $0.62^{n+*}$ & 0.20 \\
\hline Proportion of elderly members & 0.38 & 0.89 & 1.14 & 1.01 & 1.08 & 1.01 \\
\hline Proportion of elderly members ${ }^{2}$ & -0.04 & 0.97 & -0.12 & 1.04 & -0.07 & 1.04 \\
\hline Liaoning & $-0.65^{\circ *}$ & 0.30 & $1.90^{-* m}$ & 0.26 & $1.88^{+*+1}$ & 0.26 \\
\hline Jiangsui & $-0.55^{*}$ & 0.29 & $2.28^{+* *}$ & 0.20 & $2.27^{+* *}$ & 0.20 \\
\hline Henan & $-0.58^{* * *}$ & 0.29 & $1.69^{x+4}$ & 0.26 & $1.67^{* t *}$ & 0.26 \\
\hline Sichuan & $-1.90^{\text {t*t }}$ & 0.26 & $0.75^{\text {tom }}$ & 0.25 & $0.74^{*+* t}$ & 0.25 \\
\hline Gansu & $-2.03^{*+t}$ & 0.33 & $0.76^{* * *}$ & 0.27 & $0.75^{\text {sm }}$ & 0.27 \\
\hline No. of observations & 3748 & & 4296 & & 4296 & \\
\hline$R^{2}$ & 0.092 & & 0.1426 & & 0.1436 & \\
\hline
\end{tabular}

get access to the similar amount of services previously provided by the government, households have to accumulate personal wealth. Thus, the precautionary saving motive among urban households has become more and more important during this period.

Another interesting finding is the effect of unemployment on wealth accumulation. In 1995 households with unemployed members accumulate less wealth than households without unemployed members, but such differences are not statistically significant. By 1999, a 23 per cent reduction in wealth is observed for this group of households. The reason for this difference may be related to the increase in the duration of unemployment. This is because the large-scale state sector layoffs did not occur until 1994 to 1995 . The survey in 1995 may only include individuals with very short spells of unemployment. By 1999, however, some layoff workers might have been unemployed for sometime and hence may have started the process of dissaving. Note also that the result presented here is from the IV estimates, which 
Table 17.5 Determinants of net housing wealth, 1995 and 1999 (IV estimates)

\begin{tabular}{|c|c|c|c|c|c|c|}
\hline \multirow{4}{*}{$\begin{array}{l}\text { Lnmvhs } \\
\text { Constant }\end{array}$} & \multirow{2}{*}{\multicolumn{2}{|c|}{1995}} & \multicolumn{4}{|c|}{1999} \\
\hline & & & \multirow{2}{*}{\multicolumn{2}{|c|}{$\begin{array}{c}\text { Without father pty } \\
\text { Coef. Std. Err. }\end{array}$}} & \multicolumn{2}{|c|}{ With father pty } \\
\hline & Coef. & Std. Err. & & & Coef. & td. Err. \\
\hline & $15.54^{\text {tats }}$ & 5.12 & $-16.74^{* * *}$ & 5.36 & $-17.01^{*+*}$ & 5.36 \\
\hline Log permanent income & $-2.64^{* * *}$ & 0.71 & $1.70^{+*+*}$ & 0.65 & $1.67^{* *}$ & 0.66 \\
\hline Variance of household income $/ 10^{7}$ & 0.10 & 0.28 & $0.18^{\mathrm{men}}$ & 0.06 & $0.17^{*+*}$ & 0.06 \\
\hline $\mathrm{HH}$ being party member & $0.60^{\text {sse }}$ & 0.17 & $0.79^{+2 n}$ & 0.19 & $0.76^{*+1}$ & 0.19 \\
\hline Father of $\mathrm{HH}$ being pty member & & & & & $0.45^{* *}$ & 0.19 \\
\hline No, of unemployed & $-0,42^{* * *}$ & 0.20 & -0.16 & 0.18 & -0.16 & 0.18 \\
\hline $\mathrm{HH}$ age & $0.26^{*+4}$ & 0.06 & $0.14^{* *}$ & 0.06 & $0.15^{n+1+}$ & 0.06 \\
\hline $\mathrm{HH}$ age squared/100 & $-0.27^{* *}$ & 0.06 & $-0.14^{* *}$ & 0.06 & $-0.15^{\operatorname{six}}$ & 0.06 \\
\hline Gender of the $\mathrm{HH}$ & $0.76^{\text {*in }}$ & 0.16 & $0.36^{\star *}$ & 0.18 & $0.37^{*}$ & 0.18 \\
\hline Family size & $1.05^{*+*}$ & 0.20 & -0.18 & 0.22 & -0.15 & 0.23 \\
\hline No. of children & $-0.74^{n x *}$ & 0.22 & -0.23 & 0.27 & -0.24 & 0.27 \\
\hline Proportion of elderly members & 0.08 & 1.31 & 2.18 & 1.41 & 2.05 & 1.41 \\
\hline Proportion of elderly members ${ }^{2}$ & -0.42 & 1.39 & -1.47 & 1.44 & -1.36 & 1.44 \\
\hline Liaoning & -0.14 & 0.42 & $3.45^{\text {tox }}$ & 0.37 & $3.39^{\text {knt }}$ & 0.37 \\
\hline Jiangsui & $1.98^{*+*}$ & 0.42 & $4.20^{-+\infty}$ & 0.33 & $4.17^{t+1+x}$ & 0.33 \\
\hline Henan & $2.73^{n+x x}$ & 0.43 & $5.20^{\circ * x}$ & 0.36 & $5.16^{* * * x}$ & 0.36 \\
\hline Sichuan & $1.65^{n+x}$ & 0.36 & $5.51^{\text {tit }}$ & 0.33 & $5.49^{\sin }$ & 0.33 \\
\hline Gansu & $1.39^{+4+}$ & 0.48 & $4.36^{+5+1}$ & 0.36 & $4.31^{+*+}$ & 0.36 \\
\hline No. of observations & 3748 & 4296 & 4296 & & & \\
\hline $\mathrm{R}^{2}$ & 0.087 & 0.099 & 0.100 & & & \\
\hline
\end{tabular}

Table 17.6 Direct and indirect effects of unemployment and party membership on wealth, 1995 and 1999

\begin{tabular}{|c|c|c|c|c|c|c|}
\hline \multirow{2}{*}{$\begin{array}{l}\text { Net total wealth } \\
\text { Unemployment }\end{array}$} & \multicolumn{2}{|c|}{1995} & \multicolumn{2}{|c|}{1999} & \multicolumn{2}{|c|}{$\begin{array}{c}1999 \\
\text { with father party } \\
\text { Direct Indirect }\end{array}$} \\
\hline & -0.09 & -0.07 & -0.23 & -0.27 & -0.23 & -0.26 \\
\hline HH party member & 0.27 & 0.02 & 0.20 & 0.17 & 0.19 & 0.17 \\
\hline $\begin{array}{l}\text { Father party member } \\
\text { Financial wealth }\end{array}$ & & & & & 0.08 & 0.06 \\
\hline Unemployment & -0.21 & -0.21 & -0.03 & -0.54 & -0.03 & -0.54 \\
\hline HH party member & 0.42 & 0.08 & 0.29 & 0.35 & 0.27 & 0.34 \\
\hline $\begin{array}{l}\text { Father party member } \\
\text { Net housing wealth }\end{array}$ & & & & & 0.17 & 0.13 \\
\hline Unemployment & -0.42 & 0.23 & -0.16 & -0.28 & -0.16 & -0.27 \\
\hline $\mathrm{HH}$ party member & 0.60 & -0.08 & 0.79 & 0.18 & 0.76 & 0.17 \\
\hline Father party member & & & & & 0.45 & 0.07 \\
\hline
\end{tabular}


Figure 17.2 Net wealth distribution by percentile of permanent income

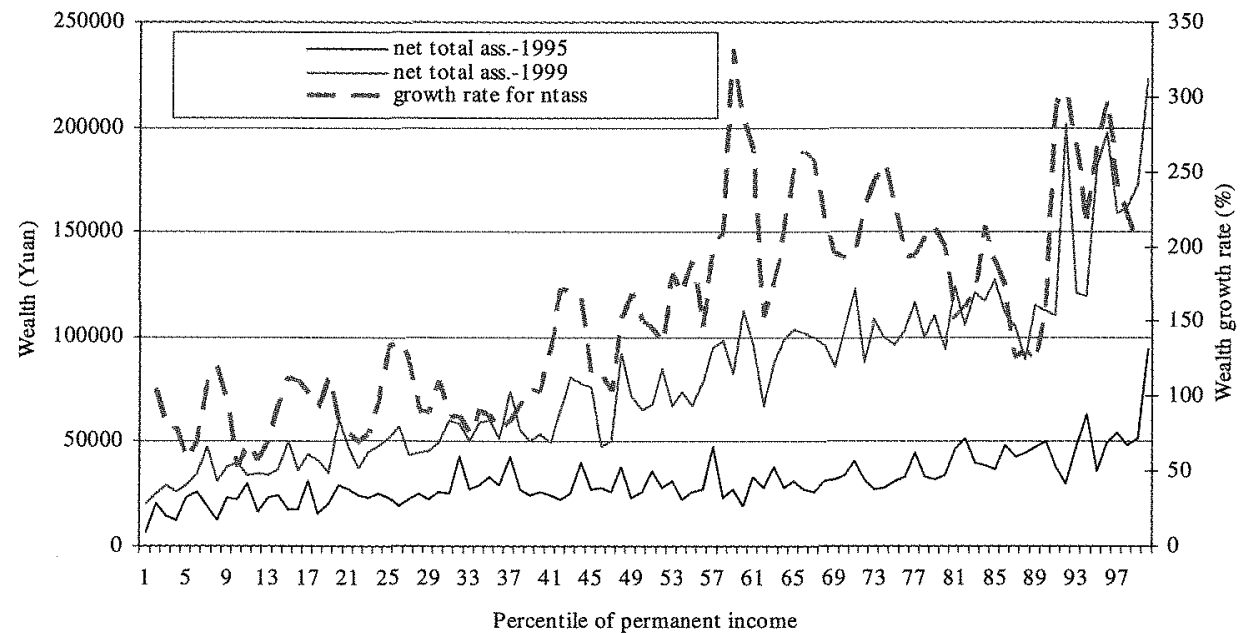

Figure 17.3 Actual and predicted net total wealth by income percentile

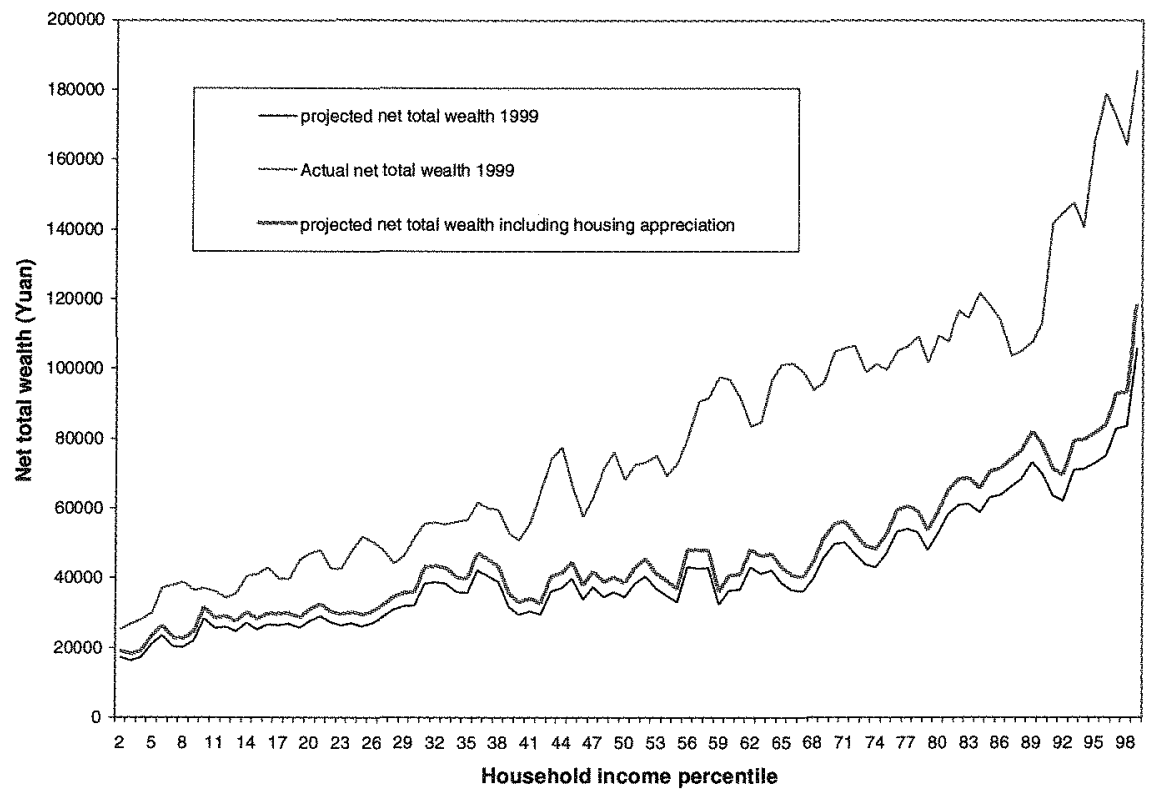


suggests that there are both direct and indirect effect of unemployment on wealth accumulation. The indirect effect is through its effect on household income. Table 17.6 reports the direct and indirect effects. It shows that a higher proportion of unemployed members has a negative effect on household permanent income in both 1995 and 1999, but the effect is twice as big in 1999 as in 1995. Taking into account that the income elasticity of wealth also doubled during this period, the indirect effect of unemployment on wealth reduction in 1999 is around 27 per cent.

The effect of party membership of the household head on wealth also has its direct and indirect components. In 1995, household net total wealth is around 27 per cent higher if a household head is a party member relative to households without a party member head, while its indirect effect through permanent income is around 2 per cent. In 1999, however, the direct effect of party membership on wealth accumulation is 20 per cent, while its indirect effect through permanent income is around 17 per cent. Thus, although the direct effect of party membership on wealth accumulation may have been slightly lower in 1999, its overall effect is actually higher in 1999 than in 1995.

The results from the estimation of the determinants of financial wealth are very similar to those of the net total wealth estimation. One noteworthy difference is that the income elasticity of wealth is very high for financial wealth relative to net total wealth, with the former ranging from 2.5 in 1995 to 3.3 in 1999. Once again, this is similar to that found in Carroll and Samwick (1997). Ruling out the possibility of inheritance, the question still remains as to whether the high saving rate of the rich is enough to explain this high discrepancy between income and wealth among households of different income levels. The answer probably is not.

The result from the net housing wealth equation for 1995 is very unusual with a negative income elasticity of housing wealth. This, however, may not be unreasonable due to a limited housing ownership (one quarter of the total households) at that stage of the housing reform. The majority of households in 1995 did not own a house, including some very rich and powerful families, who had not had the need to buy the house provided to them by the government as heavily subsidised rent lasted until much later.

The most interesting results from the net housing wealth equation is the effect of party membership. Controlling for its impact on income, in 1995 if the household head is a party member the housing asset is about 60 per cent higher than a household without a party member head. This effect increased to 79 per cent in 
1999. What is more interesting is that having a household head whose father is a party member adds another 45 per cent more in household housing assets. These results accord well with the housing distribution process described earlier. Party members and their children acquired larger and better houses before the housing reform and took advantage of the housing reform by getting better houses at substantially subsidised prices. Thus, over and above the contribution of party membership on household income, a substantial effect of party membership on housing wealth is observed together with an additional effect of inherited housing wealth from having a party member as a father is also observed.

\section{CONCLUSIONS}

Several conclusions can be drawn from this paper. First, the rate of growth of wealth is much faster than the growth of real income over the period studied. A large proportion of the increase in wealth accumulation may be through a non-saving channel. Although households at each income percentile have received an increase in non-saving wealth, it is much more so for the rich than for the poor. It is possible, therefore, that economically advantaged households have been receiving larger amounts of non-saving and non-inherited wealth such as housing bought at highly subsidised prices, gifts, or even monetary bribes, than the poor.

Second, party members and their children have benefited significantly from the wealth accumulation process. It is not only that party membership contributes positively to wealth accumulation, having a party member father also adds an additional 50 per cent increment in net housing wealth.

Third, while the precautionary motive is not apparent in the wealth accumulation in 1995, by 1999 households who have experienced large income variations over the 5 year period prior to the survey year have started saving more than households with stable income.

\section{NOTE}

1 The distribution of share of net housing wealth in net total wealth is fairly equal among different income decile, ranging from 36 per cent to 47 per cent. Hence, using average share does not change the story much. 


\section{REFERENCES}

Carroll, C. and Samwick, A.A., 1997. 'The nature of precautionary wealth', Journal of Monetary Economics, 40(1):41-71.

Morduch, J. and Sicular, T, 2000. 'Politics, growth, and inequality in rural China: does it pay to join the party?', Journal of Public Economics, 77(3):331-56.

National Statistical Bureau of China, 2000. China Statistical Yearbook, 2000, China Statistical Publishing House, Beijing.

Shamsuddin, A.F.M. and DeVoretz, D.J., 1998. 'Wealth accumulation of Canadian and foreign-born households in Canada', Review of income and Wealth, 44(4):51533 . 